JOURNAL of

TOXICOLOGY and

ENVIRONMENTAI

HEALTH
Journal of Toxicology and Environmental Health, Part A

ISSN: 1528-7394 (Print) 1087-2620 (Online) Journal homepage: https://www.tandfonline.com/loi/uteh20

\title{
In utero and lactational exposure to fipronil in female rats: Pregnancy outcomes and sexual development
}

Aline Lima de Barros, Josiane Lima Rosa, Marília Martins Cavariani, Cibele Santos Borges, Patrícia Villela e Silva, Julie Heejoo Bae, Janete Aparecida Anselmo-Franci \& Arielle Cristina Arena

To cite this article: Aline Lima de Barros, Josiane Lima Rosa, Marília Martins Cavariani, Cibele Santos Borges, Patrícia Villela e Silva, Julie Heejoo Bae, Janete Aparecida Anselmo-Franci \& Arielle Cristina Arena (2016) In utero and lactational exposure to fipronil in female rats: Pregnancy outcomes and sexual development, Journal of Toxicology and Environmental Health, Part A, 79:6, 266-273, DOI: $10.1080 / 15287394.2016 .1149132$

To link to this article: https://doi.org/10.1080/15287394.2016.1149132

曲 Published online: 13 Apr 2016.

Submit your article to this journal $\pi$

凹 Article views: 166

View Crossmark data $\subset$

Citing articles: 2 View citing articles $\square$ 


\title{
In utero and lactational exposure to fipronil in female rats: Pregnancy outcomes and sexual development
}

\author{
Aline Lima de Barros ${ }^{a}$, Josiane Lima Rosa ${ }^{a}$, Marília Martins Cavariania ${ }^{a}$ Cibele Santos Borges ${ }^{a}$, \\ Patrícia Villela e Silva ${ }^{a}$, Julie Heejoo Bae ${ }^{a}$, Janete Aparecida Anselmo-Franci ${ }^{b}$, and Arielle Cristina Arena ${ }^{a}$ \\ aDepartment of Morphology, Institute of Biosciences of Botucatu, Univ Estadual Paulista (UNESP)-Botucatu, São Paulo State, Brazil;

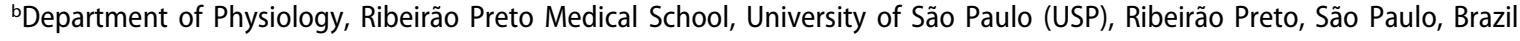

\begin{abstract}
Fipronil, a phenylpyrazole insecticide, is used in agriculture, veterinary medicine, and public health. Because this insecticide is considered a potential endocrine disruptor, the aim of this study was to examine the influence of perinatal exposure to fipronil on neonatal female reproductive system development. Pregnant rats were exposed (via gavage) daily to fipronil $(0.03,0.3$, or $3 \mathrm{mg} / \mathrm{kg}$ ) from gestational day 15 to day 7 after birth, and effects on the reproductive functions assessed on postnatal day (PND) 22. No signs of maternal toxicity were observed during daily treatment with fipronil. Perinatal exposure to the highest dose of fipronil $(3 \mathrm{mg} / \mathrm{kg})$ delayed the age of vaginal opening (VO) and first estrus without markedly affecting the anogenital distance (AGD). Further, exposure to $0.3 \mathrm{mg} / \mathrm{kg}$ fipronil produced a significantly shorter estrus cycle and reduced number of cycles during the period of evaluation. However, the other reproductive parameters analyzed, including fertility, hormone levels, sexual behavior, and histology of ovaries and uterus, displayed no marked alterations. In this experimental model, fipronil interfered with development of neonatal female reproductive system as evidenced by delay in VO and estrus cycle alterations without apparent significant effects on fertility. Further studies are needed to identify the mechanisms of action associated with the observed female reproductive system changes.
\end{abstract}

ARTICLE HISTORY

Received 14 January 2016

Accepted 28 January 2016
Several synthetic or natural agents have been identified as interacting with the endocrine system and triggering disorders on reproductive system of males and females (Yoon et al., 2014). Some substances that induce reproductive toxicity include fenvalerate (Arena et al., 2008; Nassr et al., 2010), procloraz (Sanabria et al., 2015), di- $n$-butyl phthalate (Scarano et al., 2010, Kim et al., 2010), propetamphos (Ismail and Al-Taher, 2011), diuron (Fernandes et al., 2012), glyphosate (Romano et al., 2012; Armiliato et al., 2014), and bisphenol A (Gámez et al., 2015). Exposure to these exogenous substances, referred to as endocrine disruptors (ED) (Kavlock et al., 1996; U.S. Environmental Protection Agency [EPA], 1997), produce adverse health effects, especially if exposure occurs during critical periods of development (Dickerson and Gore, 2007).

In females, some reproductive disorders, including polycystic ovary syndrome, endometriosis, accelerated puberty, masculinized genitalia, breast cancer, and disrupted hypothalamic-pituitarygonadal function, may be considered as late-onset symptoms of developmental abnormalities of the reproductive system, which may be attributed to genetic and/or environmental factors, including exposure to ED (Balabanic et al., 2011).

Fipronil is an insecticide that belongs to the phenylpyrazole chemical group. This substance is widely used in the control of many agricultural and domestic pests (Le Faouder et al., 2007; Narahashi et al., 2010; Cochran et al., 2015). In insects, the mechanism of action of this compound is to competitively block chloride channels associated with gamma-aminobutyric acid (GABA), producing death by neuronal hyperexcitation and paralysis (Zhao et al., 2004; Janssen et al., 2007; Narahashi et al., 2010). Although fipronil is considered an insecticide with selective toxicity, its major metabolite, fipronil sulfone, is at least 20-

CONTACT Arielle Cristina Arena ariellearena@ibb.unesp.br $\Theta$ Department of Morphology, Institute of Biosciences of Botucatu, São Paulo State University (UNESP), Distrito de Rubião Junior, s/n, Caixa Postal-510, CEP: 18618970, Botucatu, SP, Brazil. 
fold more potent in blocking mammalian $\mathrm{GABA}_{\mathrm{A}}$ receptors (Zhao et al., 2005). Further, fipronil and its metabolites were suggested to exert antiandrogen activity by interfering with the androgen receptor (AR) signaling pathway (Aït-Aïssa et al., 2010). These findings emphasize the need to consider fipronil as an environmental hazard, given its apparent ED potential.

Fipronil has been designated as an alternative to replace organophosphates (OP) in insect control by US Environmental Protection Agency, but Tingle et al. (2003) demonstrated its adverse effects on nontarget organisms. In addition, this pesticide was found to exert genotoxic and mutagenic effects in mice and humans (De Oliveira et al., 2010; Çelik et al., 2014) and to induce thyroid cancer in rats (Hurley, 1998), and is considered a possible ED (World Health Organization/Food and Agriculture Organizatin [WHO/FAO], 1997; Hood et al., 1999). Terçariol and Godinho (2011) noted that dermal exposure to fipronil (Frontline, Top Spot) in rats produced behavioral effects on the central nervous system, primarily involving emotions, fear, and diminished exploratory activity, indicating that this insecticide may exert neurotoxic effects.

Several studies showed that fipronil may adversely affect the female reproductive system (Ohi et al., 2004; Udo et al., 2014). Ohi et al. (2004) observed that fipronil altered plasma progesterone and estradiol levels and lengthened the estrus cycle with persistence diestrus after the application of a single dose (70, 140, and 280 $\mathrm{mg} / \mathrm{kg}$ ).

Udo et al. (2014) noted that prenatal exposure to low doses of fipronil disturbed maternal behavior with alterations in active and reflexive maternal responses. Udo et al. (2014) suggested that these alterations may be related to the GABAergic system or to endocrine disruption, since fipronil also was postulated to act as an ED.

Based on these findings, and considering that GABA inhibitors were postulated to affect the endocrine system (McCarthy, 1995; Davis et al., 1996, 2000), this study aimed to determine the influence of perinatal and postnatal exposure to fipronil on reproductive functions in neonatal female rats.

\section{Materials and methods}

\section{Animals and treatments}

Adult male $(n=40)$ (90 d of age) and female ( $n=$ 43) (60 d of age) Wistar rats, from the Central Biotherium of State University of São Paulo (UNESP), were used. Animals were maintained under controlled temperature $\left(23^{\circ} \mathrm{C}\right)$, under a 12 $\mathrm{h}$ light/dark cycle with free access to food and water. Two nonpregnant female rats were mated with one male, during the dark portion of the lighting cycle, and the day of sperm detection in the vaginal smear was considered day 0 of gestation (GD 0). Pregnant females were randomly assigned between experimental groups and housed individually in cages. The experimental procedures were in accordance with the Ethical Principles in Animal Research adopted by the Brazilian College of Animal Experimentation and approved by the Committee for Ethics in Animal Experimentation at the Institute of Biosciences/UNESP (protocol number 499/2013).

Pregnant rats were divided into four groups. One group was treated with vehicle $(1 \mathrm{ml} / \mathrm{kg}$ corn oil) and served as control. For the evaluation of the effects of fipronil (purity 97.5\%; 5-amino[(2,6-dichloro)-4-trifluoromethyl-phenyl]-4-trifluoromethyl sulfinyl-1H-pyrazol-3-carbonitrile; Sigma-Aldrich Co. Ltd.), 3 groups were treated with doses of $0.03,0.3$, or $3 \mathrm{mg} / \mathrm{kg}$ body weight. The dose regimens were based on the study of Leghait et al. (2009), who utilized a dose of 3 $\mathrm{mg} / \mathrm{kg}$ and observed changes in thyroid hormone levels. The other two doses were 10 and $100 \times$ lower than the highest dose. Fipronil was dissolved in corn oil. Experiments were conducted in the last week of pregnancy (GD 15-21) and in the first week of lactation (postnatal day [PND] 1-7) daily by oral gavage (Figure 1). The treatment period coincides with the critical period for the occurrence of hypothalamic sexual differentiation, which depends upon steroid hormones (McLusky and Naftolin, 1981).

During the treatment period, dams were weighed on alternate days to permit the calculation of the volume of fipronil to be administered and to investigate clinical signs of maternal toxicity. Behavior parameters including irritability, tremors, convulsions, lacrimation, piloerection, 


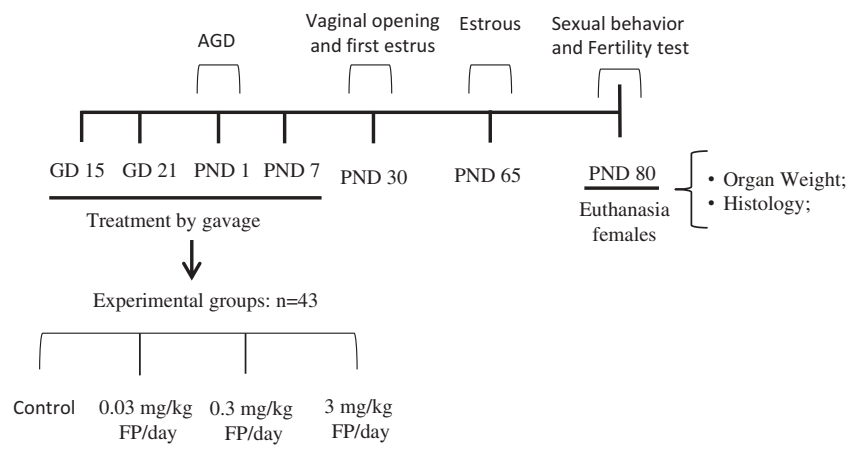

Figure 1. Experimental design.

salivation, diarrhea, and lethargy were examined, and mortality was recorded and amounts of water and feed were measured. After birth, the number of pups per litter was reduced to eight, four males and four females. The female offspring was weaned on PND21 and maintained into adulthood for assessment of reproductive parameters.

After weaning (PND21), dams were killed by $\mathrm{CO}_{2}$ inhalation and blood samples were collected by cardiac puncture. The non-anticoagulated serum samples were used for biochemical analysis, including for aspartate aminotransferase (AST), alanine aminotransferase (ALT), gamma-glutamyl transferase (gamma-GT), alkaline phosphatase (AP), glucose, creatinine, urea, sodium, potassium, calcium, cholesterol, total protein, and albumin. The Cobas Mira Plus Bio200 equipment (Katal kits) was used to determine serum chemistries. After collecting blood, the brain, pituitary gland, thyroid, heart, lung, liver, kidneys, adrenals, spleen, uteri, and ovaries were weighed.

\section{Anogenital distance and number of nipples/ areola}

At birth and at $22 \mathrm{~d}$ of age, the anogenital distance (AGD, the distance from the anus to the genital tubercle) was measured in female pups, using Vernier calipers. AGD was normalized against the cube root of body weight. Male rodents have AGD values that are approximately twice the length of those of females (Gallavan et al., 1999). On PND 13, the number of areolas was recorded. Observations were scored based on the presence or absence of a nipple bud or a discoloration of the skin surrounding the nipple (Mylchreest et al., 2000). These data were expressed as litter mean.

\section{External signs of puberty onset}

On PND 30, all females were evaluated daily for vaginal opening (VO). The day of full opening of the vaginal orifice was recorded. On the day of $\mathrm{VO}$, female rats were weighed and daily vaginal fluid was collected as described by Marcondes et al. (2002), to detect the day of first estrus (predominance of cornified epithelial cells. Ten microliters of $0.9 \%$ saline was instilled into the vagina and subsequently aspirated. Vaginal fluids were placed in a slide and analyzed under a light microscope (Leica MicroStar IV) at 200× magnification. Data were expressed as litter mean.

\section{Estrus cycle}

The estrus cycle was assessed on the basis of vaginal smears collected every morning over a period of 15 d (PND 65 to 80). The samples were observed under a light microscope and estrus cycle phases classified as diestrus, proestrus, estrus, and metaestrus. A proestrus phase consists of a predominance of nucleated epithelial cells, while estrus consists of anucleated cornified cells. A metaestrus phase consists of the same proportion among leukocytes, cornified, and nucleated epithelial cells, and the diestrus phase primarily consists of a predominance of leukocytes (Marcondes et al., 2002). The estrus cycle duration was calculated as the number of days from one estrus phase to the next.

\section{Collection and analysis of organs}

On PND 80, one female rat from each litter was sacrificed by $\mathrm{CO}_{2}$ inhalation followed by decapitation in estrus phase for collection and determination of the weight of organs, including brain, pituitary, thyroid, liver, kidneys, adrenals, uteri (with fluid), and ovaries. For histological evaluation of reproductive organs, uteri and ovaries were fixed in Bouin's solution, dehydrated in ethanol, embedded in Paraplast, sectioned at $5 \mu \mathrm{m}$ (3 sections per animal), and stained with hematoxylin and eosin (H\&E).

In each ovary, ovarian follicles and corpora lutea were counted in three sections per animal. Follicles were classified according to Guerra et al. (2010). Primordial and primary follicles were 
counted together and included oocytes surrounded by a single layer of either squamous or cuboidal epithelial cells. Follicles were classified as preantral if they contained an oocyte with a visible nucleolus and 2-4 layers of granulosa cells with no antral space. Antral follicles were classified when containing three or more layers of granulosa cells and a clearly defined antral space. Characteristics of atretic follicles included the appearance of pyknotic granulosa cells, disorganized granulosa cells, degenerating oocyte and detachment from the basement membrane. In the uterus, the endometrial height was measured in three sections per animal using a light microscope. In each section, 5 different regions were analyzed, resulting in a total of 15 measurements per animal.

\section{Serum estradiol and progesterone levels}

Blood was collected by cardiac puncture to determine serum concentrations of estradiol and progesterone. The serum was obtained by centrifugation $\left(1000 \times \mathrm{g}\right.$ for $20 \mathrm{~min}$ at $\left.4^{\circ} \mathrm{C}\right)$, and progesterone hormone levels determined by the technique of double antibody radioimmunoassay using specified kits of ImmuChem Double Antibody supplied by MP Biomedicals, LLC Diagnostic Division Orangeburg, NY. Estradiol levels were measured by enzyme-linked immunosorbent assay (ELISA) using specific kits of DRG Estradiol ELISA (EIA-2693) supplied by DRG International, Inc., USA, carried out in the Neroendocrinology Laboratory, Dental School of Ribeirão Preto, University of São Paulo-USP. All samples were dosed in the same assay, to avoid interassay errors (with a $4 \%$ intra-assay error).

\section{Sexual behavior}

During the first estrus after PND 80, female rats from different experimental groups ( 1 or 2 per litter) were used for the fertility test. Rats were maintained under controlled temperature conditions on an inverted 12-h light/dark cycle, for at least $7 \mathrm{~d}$, with food and water ad libitum. For the evaluation of female sexual behavior, sexually experienced males were allowed 10 mounts on the female and the presence of lordosis was noted. Results were expressed as the lordosis quotient (LQ, number of lordosis/10 mounts $\times$ 100) (Beach, 1976). All females were used only once.

\section{Fertility tests-natural mating}

This analysis was performed by natural mating. Female offspring (1 per litter) were placed with sexually experienced males for additional $4 \mathrm{~h}$ after the end of the sexual behavior evaluation. At the end of afternoon, rats were separated and vaginal smears collected and sperm detection determined to assess GD 0 . On GD 20, females were killed by decapitation. After collection of uteri and ovaries the numbers of corpora lutea, implants, reabsorptions, live fetuses, and dead fetuses were determined. From these results the following parameters were calculated: gestation rate: number of pregnant females/number of inseminated females $\times 100$; fertility potential (efficiency of implantation): implantation sites/corpora lutea $\times 100$; rate of preimplantation loss: [number of corpora lutea - number of implantations/number of corpora lutea] $\times 100$; rate of postimplantation loss: [number of implantations - number of live fetuses]/number of implantations $\times 100$; and sex ratio: number of male fetuses/number of female fetuses $\times 100$.

\section{Statistical analyses}

Values are expressed in mean \pm SEM and medians (Q1-Q3). For comparison of results among the experimental groups, statistical tests for analysis of variance were utilized: analysis of variance (ANOVA), with the a posteriori Tukey-Kramer test, or Kruskal-Wallis, with the a posteriori Dunn test. Differences were considered significant when $p<.05$. The statistical analyses were performed by GraphPad InStat (version 3.02).

\section{Results}

No signs of maternal toxicity were observed during the daily treatment with fipronil. Similarly, the treatment did not markedly alter maternal body weight and food and water consumption (data not shown). Dams exposed to a lower dose of fipronil displayed a significant decrease in absolute and relative weight of pituitary gland (control: $10.21 \pm$ 0.5; $0.03 \mathrm{mg} / \mathrm{kg}: 7.37 \pm 0.78 ; 0.3 \mathrm{mg} / \mathrm{kg}: 8.02 \pm 0.49$; 
A

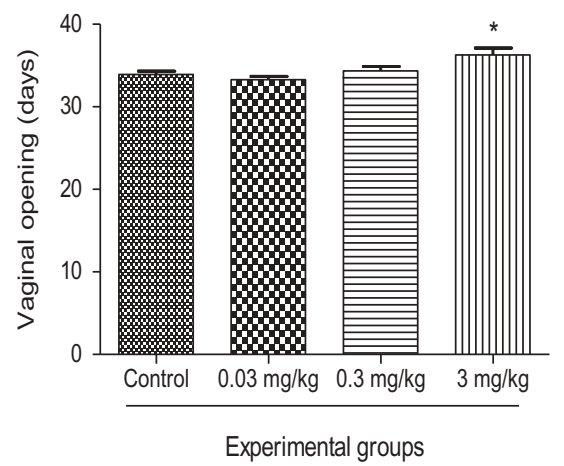

B

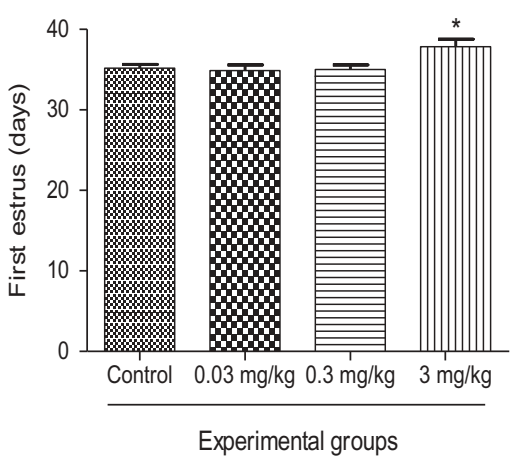

Figure 2. Vaginal opening (A) and first estrus (B) in control and exposed $0.03,0.3$ and $3 \mathrm{mg} / \mathrm{kg}$ fipronil. Values are expressed as mean \pm SEM, $9-12$ rats/group. ${ }^{*} p<0.05$. ANOVA followed by Tukey test.

$3 \mathrm{mg} / \mathrm{kg}$ : $9.28 \pm 1.15$; mean \pm SEM). However, absolute and relative weights of other organs were not significantly affected at any of the doses tested. In addition, no marked alterations in serum chemistries were noted (data not shown).

Similarly, perinatal treatment did not markedly alter body weight or AGD as well as number of nipples/areola of female offspring at birth and PND 22. Perinatal exposure to the highest dose of fipronil $(3 \mathrm{mg} / \mathrm{kg})$ delayed the age of $\mathrm{VO}$ and the first estrus (Figure 2). Further, at a dose of 0.3 $\mathrm{mg} / \mathrm{kg}$ fipronil, the duration of the estrus cycle was significantly increased and number of cycles significantly reduced during the period of evaluation (Table 1).

At PND 80, there were no significant differences among all groups in body weight and in absolute and relative weight of most of the organs. However, animals exposed to the highest dose of fipronil showed a significant fall in absolute and relative weight of the thyroid (control: $17.22 \pm$ 0.79; $0.03 \mathrm{mg} / \mathrm{kg}: 15.9 \pm 0.84 ; 0.3 \mathrm{mg} / \mathrm{kg}: 17.81 \pm$ 1.35; $3 \mathrm{mg} / \mathrm{kg}: 13.16 \pm 0.77$; mean \pm SEM).

Ovarian and uterine analysis by light microscopy did not reveal any morphological changes related to treatment (data not shown). The ovarian follicles and corpora lutea numbers and uterine endometrial height were similar among all groups (data not shown).

The lordosis quotient (LQ) also showed no marked differences among groups. Similarly, reproductive performance and estradiol and progesterone levels were not significantly affected after perinatal exposure to fipronil (data not shown).

\section{Discussion}

In this study, delayed pubertal onset (vaginal opening and first estrus) was detected in response to the highest dose of fipronil. As VO and first estrus are dependent on increased estradiol during puberty, a delay in this process may suggest antiestrogen or androgenic activities of a substance. However, other factors that are not specifically controlled by estrogen/androgen may also influence the timing of normal puberty (Grande et al., 2006). Some studies showed that fipronil exhibited antiestrogenic ( $\mathrm{Lu}$ et al., 2014) and antiandrogen (Aït-Aïssa et al., 2010) activities. Thus, this delay may be due to dysfunction of the hypothalamus-pituitary-gonadal axis associated with exposure to fipronil. Further,

Table 1 . Estrous cyclicity of female rats exposed to $0.03,0.3$, and $3 \mathrm{mg} / \mathrm{kg}$ fipronil.

\begin{tabular}{lllll}
\hline & \multicolumn{4}{c}{ Experimental groups } \\
\cline { 2 - 5 } & Control & $0.03 \mathrm{mg} / \mathrm{kg}$ & $0.3 \mathrm{mg} / \mathrm{kg}$ & $3 \mathrm{mg} / \mathrm{kg}$ \\
\cline { 2 - 5 } Proestrus & $3.70 \pm 0.19$ & $3.08 \pm 0.14$ & $3.25 \pm 0.23$ & $3.36 \pm 0.12$ \\
Estrus & $4.53 \pm 0.15$ & $4.60 \pm 0.16$ & $4.64 \pm 0.18$ & $4.58 \pm 0.27$ \\
Metaestrus & $1.62 \pm 0.14$ & $1.96 \pm 0.07$ & $2.13 \pm 0.14$ & $1.83 \pm 0.18$ \\
Diestrus & $4.52 \pm 0.19$ & $4.93 \pm 0.16$ & $4.36 \pm 0.14$ & $5.03 \pm 0.17$ \\
Number of estrus cycles & $2.96 \pm 0.05$ & $2.81 \pm 0.09$ & $2.54 \pm 0.11^{*}$ & $2.92 \pm 0.07$ \\
Estrus cycle length (d) & $4.19 \pm 0.06$ & $4.35 \pm 0.14$ & $4.81 \pm 0.26^{*}$ & $4.18 \pm 0.10$ \\
\hline
\end{tabular}

Note. Values are expressed as mean \pm SEM, $9-12$ rats/group. Significance: ${ }^{*} p<.05$. ANOVA followed by Tukey test. 
these disorders may be related to changes in receptor expression, as well as morphological changes in hypothalamic nuclei related to female reproductive system functions.

Estrus cycle monitoring is a basic method of evaluating the reproductive capacity of a female animal, and abnormality in reproductive function is often associated with estrus disruption (Shaikh et al., 1971). It was demonstrated that change in estrus cyclicity and cycle length may be related to stress, light/dark cycle (Everett et al., 1989), presence of males (Mora et al., 1985; Barkley et al., 1993), prolactin and progesterone levels (Van der Schoot and Uilenbroek, 1983; Sánchez-Criado, 1996), and exposure to pesticides (Hayashi et al., 2013; Nishi et al., 2013; Pascotto et al., 2015). In adult life, female offspring exposed to a dose of 0.3 $\mathrm{mg} / \mathrm{kg}$ fipronil showed changes in the estrus cycle, such as an increase in estrus cycle length and decrease in the number of cycles. Ohi et al. (2004) reported that fipronil treatment disrupted the normal cyclicity of female rats as evidenced by an increase in estrus cycle length with a persistent diestrus. Ohi et al. (2004) also observed a fall in estradiol and rise in progesterone levels after exposure to fipronil, and attributed these results to the stimulatory effect of the GABAergic action of fipronil at pituitary level. In our study, differences in estradiol or progesterone levels among the groups were not detected. It is possible that our conflicting results may be due to differences in experimental protocol such as treatment period, dosages, and administration route.

Data indicated that under our experimental conditions, fipronil disrupted the development of the female reproductive system, since the pesticide altered the onset of puberty and normal cyclicity of the animals. However, these changes did not persist into adulthood, since adult reproductive parameters were not markedly affected. Further studies are needed to elucidate mechanisms of action on the female reproductive system with respect to delay in $\mathrm{VO}$ and estrus cycle alterations.

\section{Conflict of interest}

The authors declare that there are no conflicts of interest.

\section{References}

Aït-Aïssa, S., Laskowski, S., Laville, N., Porcher, J. M., and Brion, F. 2010. Anti-androgenic activities of environmental pesticides in the MDA-kb2 reporter cell line. Toxicol. In Vitro 24: 1979-1985.

Arena, A. C., Fernandez, C. D., Porto, E. M., Bissacot, D. Z., Pereira, O. C., and Kempinas, W. G. 2008. Fenvalerate, a pyrethroid insecticide, adversely affects sperm production and storage in male rats. J. Toxicol. Environ. Health A 71: 1550-1558.

Armiliato, N., Ammar, D., Nezzi, L., Straliotto, M., Muller, Y. M., and Nazari, E. M. 2014. Changes in ultrastructure and expression of steroidogenic factor-1 in ovaries of zebrafish Danio rerio exposed to glyphosate. J. Toxicol. Environ. Health A77: 405-414.

Balabanic, D., Rupnik, M., and Klemencic, A. K. 2011. Negative impact of endocrine- disrupting compounds on human reproductive health. Reprod. Fertil. 23: 403-416.

Barkley, M., DeLeon, D. D., and Weste, R. 1993. Pheromonal regulation of the mouse estrous cycle by a heterogenotypic male. J. Exp. Zool. 265: 558-566.

Beach, A. 1976. Sexual attractivity, proceptivity, and receptivity in female mammals. Horm. Behav. 7: 105-138.

Çelik, A., Ekinci, S. Y., Güler, G., and Yildirim, S. 2014. In vitro genotoxicity of fipronil sister chromatid exchange, cytokinesis block micronucleus test, and comet assay. DNA Cell Biol. 33: 148-154.

Cochran, R. C., Yu, L., Krieger, R. I., and Ross, J. H. 2015. Postapplication fipronil exposure following use on pets. $J$. Toxicol. Environ. Health A 78: 1217-1226.

Davis, A. M., Grattan, D. R., Selmanoff, M., and McCarthy, M. M. 1996. Sex differences in glutamic acid descarboxylase mRNA in neonatal rat brain: Implication for sexual differentiation. Horm. Behav. 30: 538-552.

Davis, A. M., Penschuck, S., Fritschy, J. M., and McCarthy, M. M. 2000. Development switch in the expression of GABA(A) receptor subunits alpha (1) and alpha (2) in the hypothalamus and limbic system of the rat. Dev. Brain Res. 119: 127-138.

De Oliveira, P. R., Bechara, G. H., Denardi, S. E., Oliveira, R. J., and Mathias, M. I. C. 2010. Genotoxic and mutagenic effects of fipronil on mice. Exp. Toxicol. Pathol. 64: 569-573.

Dickerson, S. M., and Gore, A. C. 2007. Estrogenic environmental endocrine-disrupting chemical effects on reproductive neuroendocrine function and dysfunction across the life cycle. Rev. Endocr. Metab. Disord. 8: 143-159.

Everett, J. W. 1989. Neurobiology of reproduction in the female rat. A fifty-year perspective. Monogr. Endocrinol. 32: $1-33$.

Fernandes, G. S., Favareto, A. P., Fernandez, C. D., Bellentani, F. F., Arena, A. C., Grassi, T. F., Kempinas, W. G., and Barbisan, L. F. 2012. Effects of diuron on male rat reproductive organs: A developmental and postnatal study. J. Toxicol. Environ. Health A 75: 1059-1069.

Gallavan, R. H., Jr., Holson, J. F., Stump, D. G., Knapp, J. F., and Reynolds, V. L. 1999. Interpreting the toxicologic 
significance of alterations in anogenital distance: Potential for confounding effects of progeny body weights. Reprod. Toxicol. 13: 383-390.

Gámez, J. M., Penalba, R., Cardoso, N., Bernasconi, P. S., Carbone, S., Ponzo, O., Pandolfi, M., Scacchi, P., and Reynoso, R. 2015. Exposure to a low dose of bisphenol A impairs pituitary-ovarian axis in prepubertal rats: Effects on early folliculogenesis. Environ. Toxicol. Pharmacol. 39: 9-15.

Grande, S. W., Andrade, A. J., Talsness, C. E., Grote, K., and Chahoud, I. 2006. A dose-response study following in utero and lactational exposure to di(2-ethylhexyl)phthalate: Effects on female rat reproductive development. Toxicol. Sci. 91: 247-254.

Guerra, M. T., Scarano, W. R., Toledo, F. C., Franci, J. A. A., and Kempinas, W. G. 2010. Reproductive development and function of female rats exposed to di-butyl phthalate (DBP) in utero and during lactation. Reprod. Toxicol. 29: 99-105.

Hayashi, S., Taketa, Y., Inoue, K., Takahashi, M., Matsuo, S., Irie, K., Watanabe, G., and Yoshida, M. 2013. Effects of piperonyl butoxide on the female reproductive tract in rats. J. Toxicol. Sci. 38: 891-902.

Hood, A., Hashmi, R., and Klaassen, C. D. 1999. Effects of microsomal enzyme inducers on thyroid-follicular cell proliferation, hyperplasia, and hypertrophy. Toxicol. Appl. Pharmacol. 160: 163-170.

Hurley, P. M. 1998. Mode of carcinogenic action of pesticides inducing thyroid follicular cell tumors in rodents. Environ. Health Perspect. 106: 437-445.

Ismail, M., and Al-Taher, A. Y. 2011. Effect of propetamphos on the male rats reproductive system. Environ. Toxicol. Pharmacol. 31: 333-338.

Janssen, D., Derst, C., Buckinx, R., VandenEynden, J., Rigo, J. M., and VanKerkhove, E. 2007. Dorsal unpaired median neurons of Locusta migratoria express ivermectin- and fipronil-sensitive glutamate-gated chloride channels. J. Neurophysiol. 97: 2642-2650.

Kavlock, R. J., Daston, G. P., De Rosa, C., Fenner-Crisp, P., Gray, L. E., Kaattari, S., Lucier, G., Luster, M., Mac, M. J., Maczka, C., Miller, R., Moore, J., Rolland, R., Scott, G., Sheehan, D. M., Sinks, T., and Tilson, H. A. 1996. Research needs for the risk assessment of health and environmental effects of endocrine disruptors: A report of the U. S. EPA-sponsored workshop. Environ. Health Perspect. 104: 715-740.

Kim, T. S., Jung, K. K., Kim, S. S., Kang, I. H., Baek, J. H., Nam, H. S., Hong, S. K., Lee, B. M., Hong, J. T., Oh, K. W., Kim, H. S., Han, S. Y., and Kang, T. S. 2010. Effects of in utero exposure to di(n-butyl) phthalate on development of male reproductive tracts in Sprague-Dawley rats. J. Toxicol. Environ. Health A 73:1544-1559.

Le Faouder, J., Bichon, E., Brunschwig, P., Landelle, R., Andre, F., and Le Bizec, B. 2007. Transfer assessment of fipronil residues from feed to cow milk. Talanta 73: 710-717.

Leghait, J., Gayrard, V., Picard-Hagen, N., Camp, M., Perdu, E., Toutain, P., and Viguié, C. 2009. Fipronil-induced disruption of thyroid function in rats is mediated by increased total and free thyroxine clearances concomitantly to increased activity of hepatic enzymes. Toxicology 255: 38-44.

Lu, M., Du, J., Zhou, P., Chen, H., Lu, C., and Zhang, Q. 2014. Endocrine disrupting potential of fipronil and its metabolite in reporter gene assays. Chemosphere 120: 246-251.

Marcondes, F. K., Bianchi, F. J., and Tanno, A. P. 2002. Determination of the estrous cycle phases of rats: Some helpful considerations. Braz. J. Biol. 62: 606-614.

McCarthy, M. M. 1995. Functional significance of steroid modulation of GABAergic neurotransmission: Analysis at the behavioral, cellular and molecular levels. Horm. Behav. 29: 131-140.

McLusky, N. J., and Naftolin, F. 1981. Sexual differentiation of the central nervous system. Science 211: 1294-1303.

Mora, O. A., Sánchez-Criado, J. E., and Guisado, S. 1985. Role of the vomeronasal organ on the estral cycle reduction by pheromones in the rat. Rev. Esp. Fisiol. 41: 305-310.

Mylchreest, E., Wallace, D. G., Cattley, R. C., and Foster, P. M. D. 2000. Dose-dependent alterationsin androgen-regulated male reproductive development in rats exposed to $\mathrm{di}(n$-butyl) phthalate during late gestation. Toxicol. Sci. 55: 143-151.

Narahashi, T., Zhao, X., Ikeda, T., Salgado, V. L., and Yeh, J. Z. 2010. Glutamate-activated chloride channels: Unique fipronil targets present in insects but not in mammals. Pestic. Biochem. Physiol. 97: 149-152.

Nassr, A. C., Arena, A. C., Toledo, F. C., Bissacot, D. Z., Fernandez, C. D., Spinardi-Barbisan, A. L., Pires, P. W., and Kempinas, W. G. 2010. Effects of gestational and lactational fenvalerate exposure on immune and reproductive systems of male rats. J. Toxicol. Environ. Health A 73: 952-964.

Nishi, K., and Hundal, S. S. 2013. Chlorpyrifos induced toxicity in reproductive organs of female Wistar rats. Food Chem. Toxicol. 62: 732-738.

Ohi, M., Dalsenter, P. R., Andrade, A. J., and Nascimento, A. J. 2004. Reproductive adverse effects of fipronil in Wistar rats. Toxicol. Lett. 146:121-127.

Pascotto, V. M., Guerra, M. T., Franci, J. A., de Camargo, J. L., Kempinas, W. G., and Franchi, C. A. 2015. Effects of a mixture of pesticides on the adult female reproductive system of Sprague-Dawley, Wistar, and Lewis rats. J. Toxicol. Environ. Health A 78: 602-616.

Romano, M. A., Romano, R. M., Santos, L. D., Wisniewski, P., Campos, D. A., Souza, P. B., Viau, P., Bernardi, M. M., Nunes, M. T., and Oliveira, C. A. 2012. Glyphosate impairs male offspring reproductive development by disrupting gonadotropin expression. Arch. Toxicol. 86: 663-673.

Sanabria, M., Pessin, A., Zanutto, M. R., Perobelli, J. E., Guerra, M. T., Banzato, T. P., Borges, C. S., and Kempinas, W. G. 2015. Absence of effects on the rat sperm quality after subacute exposure to low doses of fungicide prochloraz. J. Toxicol. Environ. Health A 78: 481-491.

Sánchez-Criado, J. E., Ruiz, A., Tébar, M., and Mattheij, J. A. 1996. Follicular and luteal progesterone synergize to maintain 5-day cyclicity in rats. Rev. Esp. Fisiol. 52: 223-229. 
Scarano, W. R., Toledo, F. C., Guerra, M. T., Pinheiro, P. F., Domeniconi, R. F., Felisbino, S. L., Campos, S. G., Taboga, S. R., and Kempinas, W. G. 2010. Functional and morphological reproductive aspects in male rats exposed to di- $n$ butyl phthalate (DBP) in utero and during lactation. J. Toxicol. Environ. Health A 73: 972-984.

Shaikh, A. A. 1971. Estrone and estradiol levels in the ovarian venous blood from rats during the estrous cycle and pregnancy. Biol. Reprod. 5: 297-307.

Tingle, C. C., Rother, J. A., Dewhurst, C. F., Lauer, S., and King, W. J. 2003. Fipronil: Environmental fate, ecotoxicology, and human health concerns. Rev. Environ. Contam. Toxicol. 176: 1-66.

Terçariol, P. R. G., and Godinho, A. F. 2011. Behavioral effects of acute exposure to the insecticide fipronil. Pestic. Biochem. Physiol. 99: 221-225.

Udo, M. S. B., Sandini, T. M., Reis, T. M., Bernardi, M. M., and Spinosa, H. S. 2014. Prenatal exposure to a low fipronil dose disturbs maternal behavior and reflex development in rats. Neurotoxicol. Teratol. 45: 27-33.

U.S. Environmental Protection Agency. 1997. Special report on environmental endocrine disruption: An effect assessment and analysis. EPA/630/R-96/012. http:// archive.epa.gov/raf/web/html/special-rpt-endocrine-disrup tion.html

Van Der Schoot, P., and Uilenbroek, J. T. 1983. Reduction of 5 -day cycle length of female rats by treatment with bromocriptine. J. Endocrinol. 397: 83-89.

World Health Organization/Food and Agriculture Organization of the United Nations. 1997. Pesticide residues in food-Fipronil. Lyons, France: WHO/FAO.

Yoon, K., Kwack, S. J., Kim, H. S., and Lee, B. M. 2014. Estrogenic endocrine-disrupting chemicals: molecular mechanisms of actions on putative human diseases. J. Toxicol. Environ. Health B 17: 127-174.

Zhao, X., Yeh, J. Z., Salgado, V. L., and Narahashi, T. 2004. Fipronil is a potent open channel blocker of glutamateactivated chloride channels in cockroach neurons. J. Pharmacol. Exp. Ther. 310: 192-201.

Zhao, X., Yeh, J. Z., Salgado, V. L., and Narahashi, T. 2005. Sulfone metabolite of fipronil blocks $\delta$-aminobutyric acid and glutamate-activated chloride channels in mammalian and insect neurons. J. Pharmacol. Exp. Ther. 314: 363-373. 